\title{
Electrochemical Recovery of Phosphorus from Acidic Cheese Wastewater: Feasibility, Quality of Products, and Comparison with Chemical Precipitation
}

\author{
Yang Lei,* Zhengshuo Zhan, Michel Saakes, Renata D. van der Weijden,* and Cees J. N. Buisman
}

Cite This: ACS EST Water 2021, 1, 1002-1013

Read Online

ACCESS | L W Metrics \& More | 国 Article Recommendations | sl Supporting Information

ABSTRACT: The recovery of phosphorus (P) from high-strength acidic waste streams with high salinity and organic loads is challenging. Here, we addressed this challenge with a recently developed electrochemical approach and compared it with the chemical precipitation method via $\mathrm{NaOH}$ dosing. The electrochemical process recovers nearly $90 \%$ of $\mathrm{P}(\sim 820 \mathrm{mg} / \mathrm{L})$ from cheese wastewater in $48 \mathrm{~h}$ at $300 \mathrm{~mA}$ with an energy consumption of $64.7 \mathrm{kWh} / \mathrm{kg}$ of P. With chemical precipitation, $>86 \%$ of $\mathrm{P}$ was removed by $\mathrm{NaOH}$ dosing with a normalized cost of $1.34-1.80$ euros $/ \mathrm{kg}$ of $\mathrm{P}$. The increase in wastewater $\mathrm{pH}$ caused by $\mathrm{NaOH}$ dosing triggered the formation of calcium phosphate sludge instead of condensed solids. However, by electrochemical precipitation, the formed calcium phosphate is attached to the electrode, allowing the subsequent collection of solids from the electrode after treatment. The collected solids are characterized as amorphous calcium phosphate (ACP) at $200 \mathrm{~mA}$ or a precipitation $\mathrm{pH}$ of $\geq 9$. Otherwise, they


are a mixture of ACP and hydroxyapatite. The products have sufficient $\mathrm{P}$ content $(\leq 14 \%)$, of which up to $85 \%$ was released within $30 \mathrm{~min}$ in $2 \%$ citric acid and a tiny amount of heavy metals compared to phosphate rocks. This study paves the way for applying electrochemical removal and recovery of phosphorus from acidic P-rich wastewater and offers a sustainable substitute for mined phosphorus.

KEYWORDS: precipitation, local pH, amorphous calcium phosphate, current density, fertilizer, heavy metals

\section{INTRODUCTION}

Today, dairy processing is considered the largest industrial food wastewater source, especially in the European Union (E.U.). ${ }^{1}$ Among many others, cheese is one of the most popular dairy products. It was estimated that 1.04 and 0.61 million metric tons of cheese were produced in the E.U. and United States, respectively. ${ }^{2}$ Along with the production of cheese, a large amount of cheese wastewater was generated. The composition of cheese wastewater is affected by the type of cheese produced and the manufacturing process. However, in general, cheese wastewater is characterized by high salinity, a high load of organic content, and a high phosphate concentration. ${ }^{1,3,4}$

Conventionally, biological processes, including aerobic and anaerobic digestion, have been applied to treat cheese wastewater. ${ }^{1,3-5}$ The biological process, however, mainly focuses on reducing COD or BOD and the production of biogas from cheese wastewater. ${ }^{6}$ Less attention has been paid to removing nutrients, although nutrients (i.e., phosphate) are removed to some extent by uncontrolled coprecipitation with sludge. Apart from the biological process, physicochemical treatment was also suggested. ${ }^{4,5,7}$ Prazeres and co-authors investigated the pretreatment of cheese wastewater by chemical precipitation and achieved the reduction of COD, turbidity, and nutrients to some extent. ${ }^{8-10}$

While physicochemical treatment of cheese wastewater via dosing of alkaline or acidic chemicals is relatively simple and effective and thus has been widely studied, ${ }^{8-11}$ using strong corrosive chemicals remains a major challenge for widespread implementation because of safety concerns in transporting, storing, and disposing of those corrosive chemicals.

Encouragingly, the use of electrochemical approaches opens the door for chemical-free treatment strategies. ${ }^{12-15}$ Electrocoagulation has been suggested as a robust treatment strategy for dairy wastewater. ${ }^{16,17}$ Markou et al. further studied the post-treatment of aerobically pretreated dairy wastewaters by electrochemical oxidation using dimensionally stable anodes. It achieved almost complete removal of $3700 \mathrm{mg} / \mathrm{L} \mathrm{COD} \mathrm{in} 6 \mathrm{~h}$ in the presence of $0.2 \mathrm{~mol} / \mathrm{L} \mathrm{NaCl}^{18} \mathrm{~A}$ combined electro-

Received: November 20, 2020

Revised: February 18, 2021

Accepted: February 18, 2021

Published: March 1, 2021

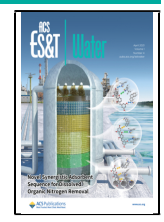


coagulation and electrochemical oxidation process was also suggested for the treatment of dairy wastewater. ${ }^{19}$ In particular, it was found that electrochemical treatment can result in the disinfection of dairy wastewater, along with the removal of organic loads. $^{20}$

While the treatment of dairy wastewater, including cheese wastewater, has been well-documented, most of these case studies and research efforts have been limited to properly treating waste streams without taking the recovery of nutrients into account. Moreover, there is no specific case addressing simultaneous phosphorus removal and recovery from cheese wastewater. Phosphorus is an essential nutrient element for all life forms. The use of phosphorus fertilizer plays a crucial role in guaranteeing crop yield and providing food for a growing global population. ${ }^{21}$ Unfortunately, our current production of phosphorus fertilizer from mined phosphate rock is not sustainable, as phosphate rock is a finite resource and only a few countries have phosphate rocks. ${ }^{22,23}$ On the contrary, the high phosphate concentration in acidic cheese wastewater can be problematic (i.e., eutrophication) if not adequately treated. $^{10}$

We previously developed a novel electrochemical approach for phosphorus removal and recovery. ${ }^{24}$ In the electrochemical system, the reduction of $\mathrm{H}_{2} \mathrm{O}$ molecules establishes a high local $\mathrm{pH}$ near the cathode. The high $\mathrm{pH}$ then drives calcium phosphate formation and precipitation on the cathode surface. ${ }^{12}$ While this electrochemical system had shown good performance in the removal and recovery of phosphorus from domestic wastewater, ${ }^{13,25}$ the adoption of this system in treating domestic wastewater is limited by the high energy consumption and low calcium phosphate purity of recovered products. The low phosphate concentration with a high concentration of (bi)carbonate in domestic wastewater leads to the dominant formation of calcium carbonate. Therefore, we conclude that the electrochemical phosphorus recovery system is not suitable for treating low-strength wastewater with low phosphate but high (bi)carbonate but maybe feasible for treating high-strength phosphorus-rich wastewater, i.e., cheese wastewater.

However, to the best of our knowledge, the feasibility and efficiency of this system toward real cheese wastewater, which has a very high organic load $(\sim 20 \mathrm{~g} / \mathrm{L}$ COD $)$ and an acidic environment $(\mathrm{pH}<5.0)$, has not been assessed. It is wellknown that a high level of organics and a low $\mathrm{pH}$ inhibit calcium phosphate precipitation. ${ }^{26}$ Therefore, the feasibility of electrochemically induced calcium phosphate precipitation in cheese wastewater needs to be clarified. We should also assess the property and quality of the recovered products by this electrochemical method for their potential as a substitute $\mathrm{P}$ source. Moreover, it is not clear if this electrochemical approach has advantages over the typically applied chemical precipitation approach.

Therefore, we investigated the treatment of cheese wastewater, focusing on phosphorus removal and recovery by electrochemically induced calcium phosphate precipitation. It is worth mentioning that the proposed electrochemical approach is very different compared to the conventional electrocoagulation process, which is based on the corrosion of sacrificial metal electrodes. ${ }^{15}$ We performed a systematic evaluation of the electrochemical approach regarding feasibility, efficiency, property, and quality of recovered products and compared it with conventional chemical precipitation via $\mathrm{NaOH}$ dosing. The results from this study were expected to advance our understanding of the feasibility and potential of electrochemical phosphorus recovery in high-strength acidic waste streams and facilitate its adoption as a promising pretreatment strategy after subsequent optimization in cell design and operation.

\section{MATERIALS AND METHODS}

2.1. Materials. The titanium-based electrodes (anode and cathode coated with galvanic $\mathrm{Pt}$ ) were provided by MAGNETO Special Anodes B.V. (Schiedam, The Netherlands). $\mathrm{NaOH}$ and $\mathrm{HNO}_{3}$ were purchased from VWR (Leuven, Belgium). The commercial hydroxyapatite [HAP, $\left.\mathrm{Ca}_{5}(\mathrm{OH})\left(\mathrm{PO}_{4}\right)_{3}\right]$ used as a reference in solid characterizations was received from Sigma-Aldrich.

2.2. Cheese Wastewater. The raw cheese wastewater was obtained from a local industrial wastewater treatment plant (Groningen, The Netherlands) and stored in a $4{ }^{\circ} \mathrm{C}$ refrigerator. This industrial wastewater treatment plant was built to treat industrial wastewater in this region, together with cheese wastewater. This region is famous for dairy product production in Europe. It is worth mentioning that the treatment plant operator is looking for a pretreatment technology to pretreat cheese wastewater before mixing it with other industrial waste and treatment in the activated sludge processes. Sedimentations may already occur in the buffer tank in the industrial wastewater treatment plant, and thus, the sampled wastewater has a very low suspended solid content. The analysis of total and soluble COD and P indicates that soluble species dominate the wastewater. Considering this characteristic, we reported only the soluble contents of cheese wastewater unless otherwise specified, as this can reflect the change in wastewater composition.

2.3. Experimental Setup and Design. The electrolysis setup is the same as that described previously. ${ }^{27,28}$ The electrochemical cell has an empty volume of $\sim 1.0 \mathrm{~L}$. In each test, we added $0.9 \mathrm{~L}$ of cheese wastewater to the electrochemical cell. The wastewater in the reactor was mixed by a peristaltic pump at a rate of $150 \mathrm{~mL} / \mathrm{min}$. The anode was a platinum $(\mathrm{Pt})$-coated titanium $(\mathrm{Ti})$ mesh of $\varnothing 8 \mathrm{~cm}$. The cathode was a Pt-Ti plate (thickness of $1 \mathrm{~mm}, \varnothing 8 \mathrm{~cm}$ ). The projected surface area of all electrodes was approximately 0.005 $\mathrm{m}^{2}$. The round-shaped electrodes were fixed horizontally inside the reactor, and the cathode was positioned below the anode with a gap of $3 \mathrm{~cm}$. $\mathrm{Pt}-\mathrm{Ti}$ rods $(\varnothing 3 \mathrm{~mm})$ were perpendicularly welded to the electrodes and used for power connection. The electrochemical precipitation tests were performed under constant current mode, and the needed cell voltage was provided by a power supply (ES 030-5, Delta Electronics B.V.). The electrochemical system's performance was studied under electric currents of 50, 100, 200, and 300 $\mathrm{mA}$. All experiments were conducted at room temperature $(T$ $=23 \pm 1{ }^{\circ} \mathrm{C}$ ) and were performed in triplicate, and the data are presented as the mean with the standard deviation.

2.4. Collection of Precipitates. At the end of each experiment, we removed the treated wastewater in the reactor carefully by syringe to minimize the disturbance of the precipitates on the cathode. The cathode with deposits was airdried at room temperature for $72 \mathrm{~h}$. After drying, we collected the solids by gentle scraping, washed them with Milli- $Q$ water to remove $\mathrm{NaCl}$, and then air-dried the solids again before characterizing the solids. We then cleaned the used cathode with an acidic medium $\left(0.1 \mathrm{M} \mathrm{HNO}_{3}\right)$ and thoroughly flushed it with Milli-Q water. 
We also tried to identify how much of the removed phosphorus precipitated on the cathode. In this case, the deposits on the cathode were completely dissolved in a $1 \mathrm{M}$ $\mathrm{HNO}_{3}$ solution $(0.5 \mathrm{~L})$, and the associated concentrations of $\mathrm{Ca}, \mathrm{Mg}$, and $\mathrm{P}$ were determined. The precipitates formed in the bulk wastewater were collected through vacuum filtering using paper filters and then analyzed in the same way as the precipitates on the cathode.

2.5. Chemical Precipitation Tests. For comparison, we also investigated the feasibility of chemical precipitation on the removal and recovery of phosphorus from cheese wastewater. We added $500 \mathrm{~mL}$ of cheese wastewater to a $1.0 \mathrm{~L}$ beaker. We used a concentrated $\mathrm{NaOH}$ solution $(10 \mathrm{M})$ to alkalify cheese wastewater from its original $\mathrm{pH}$ value (4.4) to $\mathrm{pH} 7.0,8.0,9.0$, 10.0, and 11.0. We applied a magnetic stirrer to ensure efficient mixing of the wastewater during the $\mathrm{pH}$ adjustment process. After the wastewater $\mathrm{pH}$ had been increased to the desired value, the well-mixed solution was allowed to settle for $24 \mathrm{~h}$. Liquid samples were taken at 0.5 and $24 \mathrm{~h}$ during the settlement process and analyzed in the same way as in the electrochemical method. Before the analysis, samples were filtered through a $0.45 \mu \mathrm{m}$ membrane filter. For the samples taken at $0.5 \mathrm{~h}$, part of the samples was immediately acidified with concentrated acid $\left(1 \mathrm{M} \mathrm{HNO}_{3}\right)$ to measure the total $\mathrm{P}$, in addition to the soluble P concentration. After settling for $24 \mathrm{~h}$, the sludge generated from chemical treatment was recovered by vacuum filtration using paper filters $(8 \mu \mathrm{m}$ pore size $)$. The recovered thick sludge was air-dried at room temperature. To characterize the solid, the dried solids were washed with Milli$\mathrm{Q}$ water to remove $\mathrm{NaCl}$ in the same way as in the electrochemical process.

2.6. Analytical Methods. We applied ICP-AES (Optima $5300 \mathrm{DV}$, PerkinElmer) to quantify the concentrations of $\mathrm{P}$, $\mathrm{Ca}$, and $\mathrm{Mg}$ and the elemental composition of completely dissolved precipitates. We measured $\mathrm{PO}_{4}{ }^{3-}, \mathrm{Cl}^{-}$, and $\mathrm{SO}_{4}{ }^{2-}$ by ion chromatography (Compact IC 761, Metrohm), equipped with a Metrosep A Supp 4/5 Guard precolumn, a Metrohm Metrosep A 122 Supp $5(150 / 4.0 \mathrm{~mm})$ column, and a conductivity detector. Samples for ICP-AES and IC analysis were filtrated through a $0.45 \mu \mathrm{m}$ membrane filter. We analyzed the wastewater $\mathrm{pH}$ and conductivity by a $\mathrm{pH}$ meter and conductivity detector (Seven Excellence S470, Mettler Toledo). We used cuvette LCK 114 (150-1000 mg/L) to check the COD values for all samples after proper dilution. It is worth noting that samples for soluble COD analysis were filtered with a $0.45 \mu \mathrm{m}$ membrane filter. We determined the concentrations of total nitrogen and ammonium in cheese wastewater using cuvette LCK $138(1-16 \mathrm{mg} / \mathrm{L})$ and LCK $304(0.02-2.50 \mathrm{mg} / \mathrm{L})$. We quantified the total organic carbon (TOC) by a TOC-LCPH analyzer equipped with an ASI-L autosampler (Shimadzu) with a $1.0 \mathrm{mg} / \mathrm{L}$ detection limit.

2.7. Characterization of Solids. We identified the phases of the collected solids by X-ray diffraction (XRD) and determined their elemental composition by ICP-AES after acid digestion. Briefly, $\sim 0.05 \mathrm{~g}$ of solids was dissolved in $2 \mathrm{~mL}$ of $70 \% \mathrm{HNO}_{3}$ and diluted properly for subsequent ICP-AES analysis. We applied Raman to check the bond information about the recovered products. Details about the instruments can be found elsewhere. ${ }^{12,29}$

2.8. Bioavailability. The $\mathrm{P}$ bioavailability of recovered solids was evaluated by the solubility of recovered solids in water and $2 \%$ citric acid solutions. This method is adapted from the standard protocols suggested by the German
Agriculture Institutes. ${ }^{30}$ Briefly, 0.25 g of ground solids was exposed to $25 \mathrm{~mL}$ of a $2 \%$ citric acid solution $(25 \mathrm{~mL})$ or Milli$\mathrm{Q}$ water under continuous rotation at $80 \mathrm{rpm}$. After $0.5 \mathrm{~h}$, the mixed solutions were filtered with a $0.45 \mu \mathrm{m}$ membrane filter and then diluted properly for ICP-AES analysis.

2.9. Calculation. The fractions of $\mathrm{P}, \mathrm{Ca}$, and $\mathrm{Mg}$ in cheese wastewater as a $\mathrm{pH}$ function were calculated with HydraMedusa software. ${ }^{31}$ The input was based on the main composition of the wastewater. The ionic strength was calculated to be $4.0 \mathrm{M}$.

\section{RESULTS AND DISCUSSION}

3.1. Thermodynamic Insights from Cheese Wastewater Composition. We can see from Table 1 that the

Table 1. Main Physicochemical Composition of Cheese Wastewater

\begin{tabular}{lll}
\hline \multicolumn{1}{c}{ parameter } & mass concentration & molar concentration \\
$\mathrm{Na}^{+}$ & $87.1 \pm 1.0 \mathrm{~g} / \mathrm{L}$ & $3.79 \pm 0.04 \mathrm{M}$ \\
$\mathrm{Ca}^{2+}$ & $2173 \pm 83 \mathrm{mg} / \mathrm{L}$ & $54.3 \pm 2.1 \mathrm{mM}$ \\
$\mathrm{Mg}^{2+}$ & $138.3 \pm 3.4 \mathrm{mg} / \mathrm{L}$ & $5.69 \pm 0.14 \mathrm{mM}$ \\
$\mathrm{NH}_{4}{ }^{+}$ & $76.6 \pm 6.2 \mathrm{mg} / \mathrm{L}$ & $4.26 \pm 0.34 \mathrm{mM}$ \\
$\mathrm{Cl}^{-}$ & $106.9 \pm 5.0 \mathrm{~g} / \mathrm{L}$ & $3.01 \pm 0.14 \mathrm{M}$ \\
$\mathrm{PO}_{4}{ }^{3-}$ & $2390 \pm 45 \mathrm{mg} / \mathrm{L}$ & $25.2 \pm 0.5 \mathrm{mM}$ \\
$\mathrm{SO}_{4}{ }^{2-}$ & $257 \pm 6 \mathrm{mg} / \mathrm{L}$ & $2.68 \pm 0.06 \mathrm{mM}$ \\
total soluble P & $827 \pm 23 \mathrm{mg} / \mathrm{L}$ & $26.7 \pm 0.7 \mathrm{mM}$ \\
total N & $496 \pm 49 \mathrm{mg} / \mathrm{L}$ & $35.4 \pm 3.5 \mathrm{mM}$ \\
total carbon & $7.72 \pm 0.13 \mathrm{~g} / \mathrm{L}$ & $0.64 \pm 0.01 \mathrm{M}$ \\
total organic carbon & $7.71 \pm 0.13 \mathrm{~g} / \mathrm{L}$ & $0.64 \pm 0.01 \mathrm{M}$ \\
total COD & $19.8 \pm 0.2 \mathrm{~g} / \mathrm{L}$ & $\mathrm{N} / \mathrm{A}$ \\
soluble COD & $19.7 \pm 0.3 \mathrm{~g} / \mathrm{L}$ & $\mathrm{N} / \mathrm{A}$ \\
$\mathrm{pH}$ & $4.4 \pm 0.1$ & $\mathrm{~N} / \mathrm{A}$ \\
conductivity & $208.8 \pm 0.4$ & $\mathrm{mS} / \mathrm{cm}$ \\
\hline
\end{tabular}

wastewater has an exceptionally high salinity and a high organic load, as revealed by the very high $\mathrm{Na}$ and $\mathrm{Cl}$ contents and the high COD. The analysis of total and soluble COD and $\mathrm{P}$ suggests that soluble species dominate the sampled wastewater. Considering this characteristic, we reported the concentration of only most soluble species unless specified, as this is very close to the total concentration. Cheese wastewater contains $827 \pm 23 \mathrm{mg} / \mathrm{L} \mathrm{P}$ and $2173 \pm 83 \mathrm{mg} / \mathrm{L} \mathrm{Ca}$. The $\mathrm{P}$ concentration in cheese wastewater is $\sim 100$ times that of the influent of domestic sewage, highlighting the recovery potential of cheese wastewater as a source of $\mathrm{P}$. The $\mathrm{Ca} / \mathrm{P}$ molar ratio in cheese wastewater is 2.0 , which is higher than the atomic ratio of the most stable calcium phosphate ( $\mathrm{HAP}, \mathrm{Ca} / \mathrm{P}=1.67)$. This indicates that there are enough coexisting calcium ions in the wastewater to precipitate phosphorus. The wastewater also has $76.6 \mathrm{mg} / \mathrm{L} \mathrm{NH}_{4}^{+}$and $130 \mathrm{mg} / \mathrm{L} \mathrm{Mg}$. The low concentrations of $\mathrm{Mg}^{2+}$ and $\mathrm{NH}_{4}^{+}$relative to phosphate omit the choice of removing and recovering phosphorus from cheese wastewater via struvite formation and precipitation. Therefore, it is apparent that the most suitable way to remove and recover $\mathrm{P}$ from cheese wastewater is by calcium phosphate precipitation.

We applied Hydra-Medusa to calculate the fractions of $\mathrm{P}$ and $\mathrm{Ca}$ in cheese wastewater as a function of $\mathrm{pH}$ (panels $\mathrm{A}$ and $\mathrm{B}$, respectively, of Figure 1). The thermodynamic calculation suggests that the wastewater is not saturated with any minerals at a background $\mathrm{pH}$ of 4.4. The $\mathrm{P}$ in the wastewater was in the form of $\mathrm{H}_{2} \mathrm{PO}_{4}^{-}$. The simulation projects the partial formation 


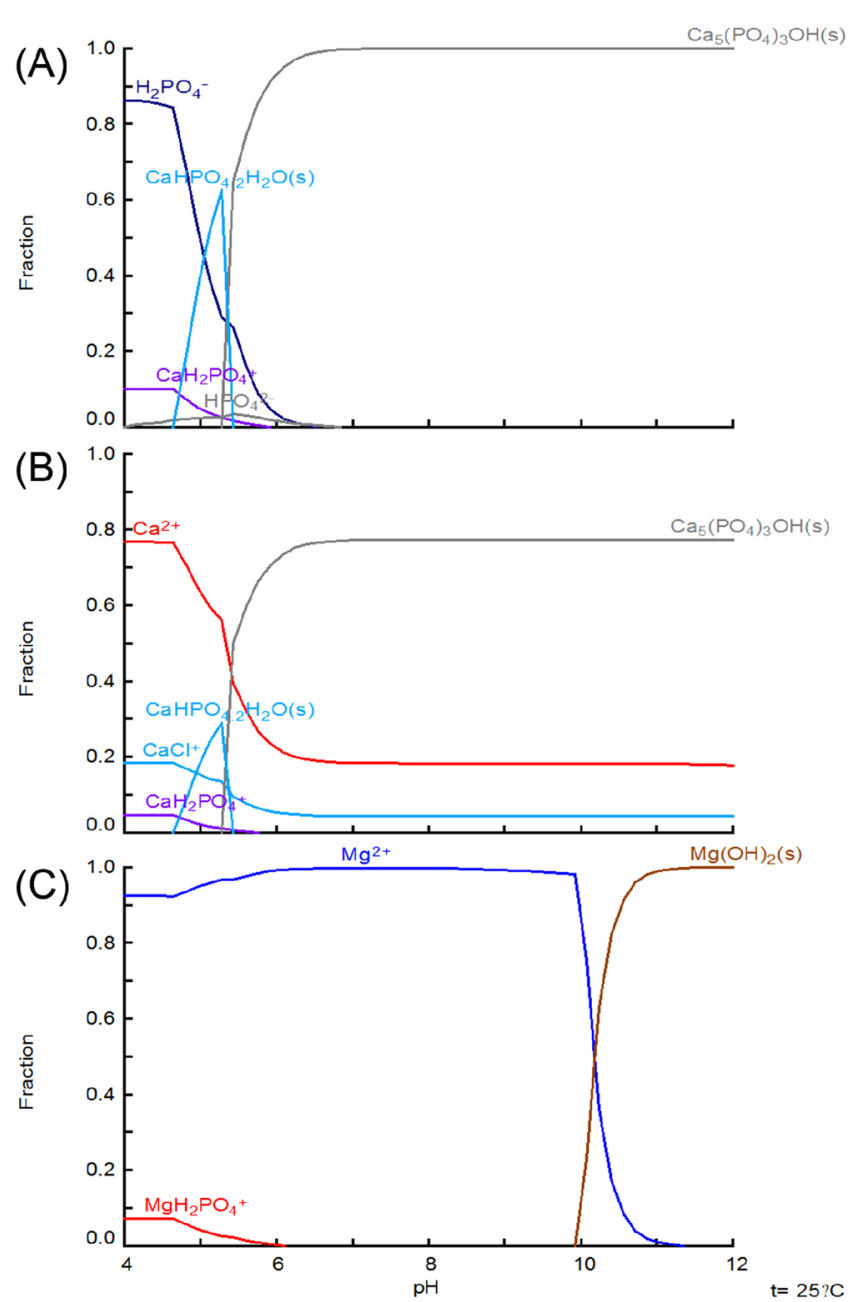

Figure 1. (A) $\mathrm{P},(B) \mathrm{Ca}$, and (C) $\mathrm{Mg}$ fractions as a function of $\mathrm{pH}$, calculated with Medusa-Hydra software. The input was based on the main wastewater composition, as given in Table 1 . The ionic strength was calculated to be $4.0 \mathrm{M}$.

of brushite $\left(\mathrm{CaHPO}_{4} \cdot 2 \mathrm{H}_{2} \mathrm{O}\right)$ at $\mathrm{pH} \sim 5.0$. When the solution $\mathrm{pH}$ is increased to $>6.0$, the solution becomes highly saturated with regard to HAP. Theoretically, nearly $100 \%$ of the P in cheese wastewater will be present in the form of solid HAP at $\mathrm{pH} \geq 6.0$; however, it is worth mentioning that such thermodynamic simulation refers to the equilibrium status and does not guarantee the formation of visible precipitates within the time frame of our tests. ${ }^{32}$ For $\mathrm{Mg}$, regardless of the wastewater $\mathrm{pH}$, it will not help to remove phosphate in our system. The calculation of the $\mathrm{Mg}$ fraction indicates that $\mathrm{Mg}$ is mainly present as free $\mathrm{Mg}^{2+}$ unless the $\mathrm{pH}$ is increased to $>10.0$, where $\mathrm{Mg}(\mathrm{OH})_{2}$ appears as the dominant species (Figure 1C).

3.2. Chemical Precipitation. On the basis of the thermodynamic calculation, the calcium phosphate species in cheese wastewater will become highly saturated when the $\mathrm{pH}$ is $>6.0$. In our tests, we observed an apparent formation of suspended solids when cheese wastewater $\mathrm{pH}$ reached 6.5. At $\mathrm{pH}$ 7.0, the concentrations of $\mathrm{P}$ and Ca decreased from $827 \pm$ 23 and $2173 \pm 83 \mathrm{mg} / \mathrm{L}$ to $119 \pm 4$ and $1043 \pm 137 \mathrm{mg} / \mathrm{L}$, respectively, which correspond to removal efficiencies of $85.6 \%$ for $\mathrm{P}$ and $52.0 \%$ for $\mathrm{Ca}$ (Figure $2 \mathrm{~A}$ ). When the wastewater $\mathrm{pH}$ was increased to $>8.0,>90.0 \%$ of $\mathrm{P}$ and $>64.2 \%$ of Ca were removed. The removal of $\mathrm{Mg}$ strongly depends on the $\mathrm{pH}$, with an only $24.6 \%$ reduction at $\mathrm{pH} 7.0,43.5 \%$ at $\mathrm{pH} 10.0$, but $77.5 \%$ at $\mathrm{pH} 11.0$. The removal of $\mathrm{Mg}$ is mainly due to the formation and precipitation of $\mathrm{Mg}(\mathrm{OH})_{2}$, which requires a $\mathrm{pH}$ of $>10.0$, according to the thermodynamic calculation (Figure $1 \mathrm{C})$.

Additionally, Mg's incorporation into the calcium phosphate lattice structure might also contribute to the removal of $\mathrm{Mg}$ to some extent, ${ }^{33}$ especially at $\mathrm{pH} \leq 9.0$, where $\mathrm{Mg}(\mathrm{OH})_{2}$ formation is not thermodynamically favored. With regard to COD, we did not observe an apparent removal of COD (see Figure S1), which is in contrast to Prazeres' report. ${ }^{9}$ They observed a COD reduction at the range of $10.2-43.7 \%$ from cheese wastewater after $\mathrm{NaOH}$ dosing. This difference is probably caused by the very different cheese wastewater composition. Our sampled wastewater is dominated by soluble species and has a much higher COD/P ratio (24.9) compared to that of Parazeres (1.45).

Even though $\mathrm{NaOH}$ dosing effectively triggers the formation of calcium phosphate in cheese wastewater, it has an apparent disadvantage. Figure 2B shows that a significant amount of sludge was generated in cheese wastewater after $\mathrm{NaOH}$ dosing. Moreover, the formed sludge has a poor settleability. The analysis of total $\mathrm{P}$ (as an indication of precipitation efficiency) and soluble $\mathrm{P}$ (removal efficiency) after $0.5 \mathrm{~h}$ indicates that although calcium phosphate precipitates formed, they did not settle (Figure S2). For example, the $\mathrm{P}$ removal efficiency after settling for $0.5 \mathrm{~h}$ was as high as $95.5 \%$ at $\mathrm{pH} 9.0$, whereas the precipitation efficiency was only $58.1 \%$. According to our observation, the sludge's height formed in the beaker stabilized $\sim 6 \mathrm{~h}$ after adjustment of the $\mathrm{pH}$. After $24 \mathrm{~h}$, we observed a clear sludge sedimentation (see Figure $2 \mathrm{~B}$ ). At $\mathrm{pH} \geq 8.0$, the generated sludge accounts for $70 \%$ of the volume of the treated wastewater. Increasing the reaction time to 1 week did not improve the settleability of the generated chemical sludge. The formation of a large amount of sludge significantly impacts the overall cost by the traditional chemical precipitation method as the formed chemical sludge needs to be appropriately treated.

The XRD characterizations of collected precipitates suggest that the crystallinity of calcium phosphate decreases with the precipitation $\mathrm{pH}$ (Figure 3A). At $\mathrm{pH} 7.0$, the solids are a mixture of HAP and amorphous calcium phosphate (ACP). The broadened peak around a $2 \theta$ of $30^{\circ}$ can be an indicator of the presence of $\mathrm{ACP} .{ }^{34}$ In contrast, the well-matched peaks at $2 \theta$ values of $26^{\circ}, 32^{\circ}$, and $50^{\circ}$ against the reference HAP spectrum indicate the formation of crystalline calcium phosphate. The solids collected at a precipitation $\mathrm{pH}$ of $\geq 9.0$ are dominated by ACP, as evidenced by the lack of sharp peaks in the corresponding XRD patterns. ${ }^{13}$ Compared to the solids collected at $\mathrm{pH} \mathrm{7.0,} \mathrm{the} \mathrm{typical} \mathrm{patterns} \mathrm{that} \mathrm{are} \mathrm{assigned} \mathrm{to}$ $\mathrm{HAP}$ disappeared at $\mathrm{pH} \geq 9.0$. Our results are in line with the previous finding that the degree of crystallinity decreased with $\mathrm{pH}^{33,35}$

The Raman characterization also supports the shift of the calcium phosphate phase as a function of precipitation $\mathrm{pH}$. While all Raman spectra show characteristic vibration $\mathrm{P}-\mathrm{O}$ bonds, including the leading $v_{1}\left(\mathrm{PO}_{4}\right)$ stretching that lies between 950 and $960 \mathrm{~cm}^{-1}$ (Figure 3B), there is a definite shift in the exact position of the $v_{1}\left(\mathrm{PO}_{4}\right)$ stretching (Figure 3C). At $\mathrm{pH} 7.0$, the $v_{1}\left(\mathrm{PO}_{4}\right)$ stretching occurs at $961 \mathrm{~cm}^{-1}$, very close to the reference spectrum of HAP. However, at $\mathrm{pH} 9.0$ and 11.0, the $v_{1}\left(\mathrm{PO}_{4}\right)$ stretching occurs at $951 \mathrm{~cm}^{-1}$ (Figure 3C). It is well documented that the $v_{1}\left(\mathrm{PO}_{4}\right)$ stretching of HAP typically occurs around $960 \mathrm{~cm}^{-1}$, whereas for ACP, it appears 


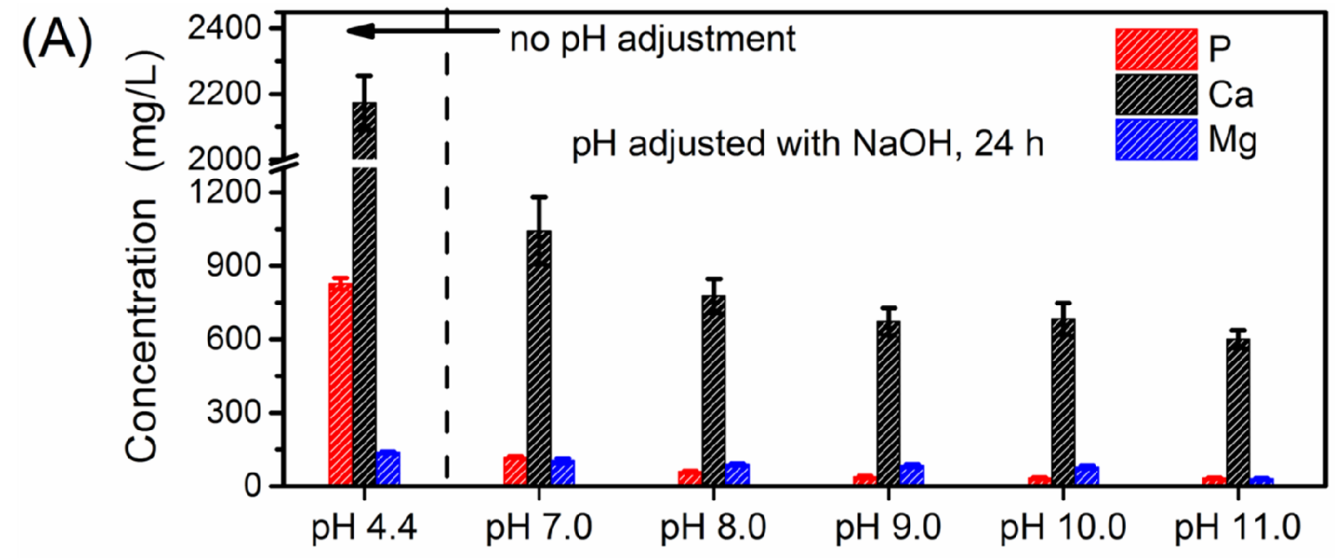

(B)

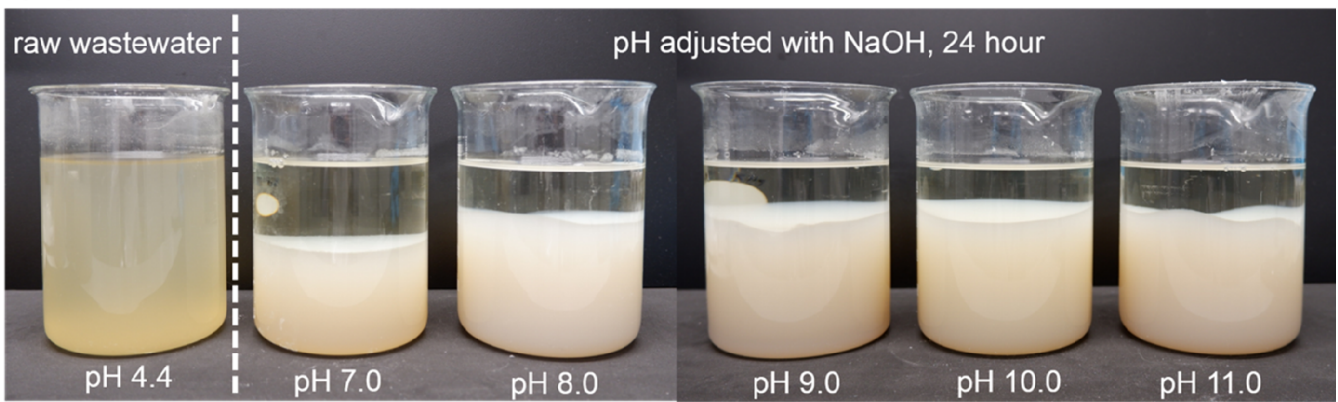

Figure 2. (A) Removal of $\mathrm{P}, \mathrm{Ca}$, and $\mathrm{Mg}$ from cheese wastewater by chemical precipitation. (B) Real images of raw and treated cheese wastewater at different precipitation $\mathrm{pH}$ values.
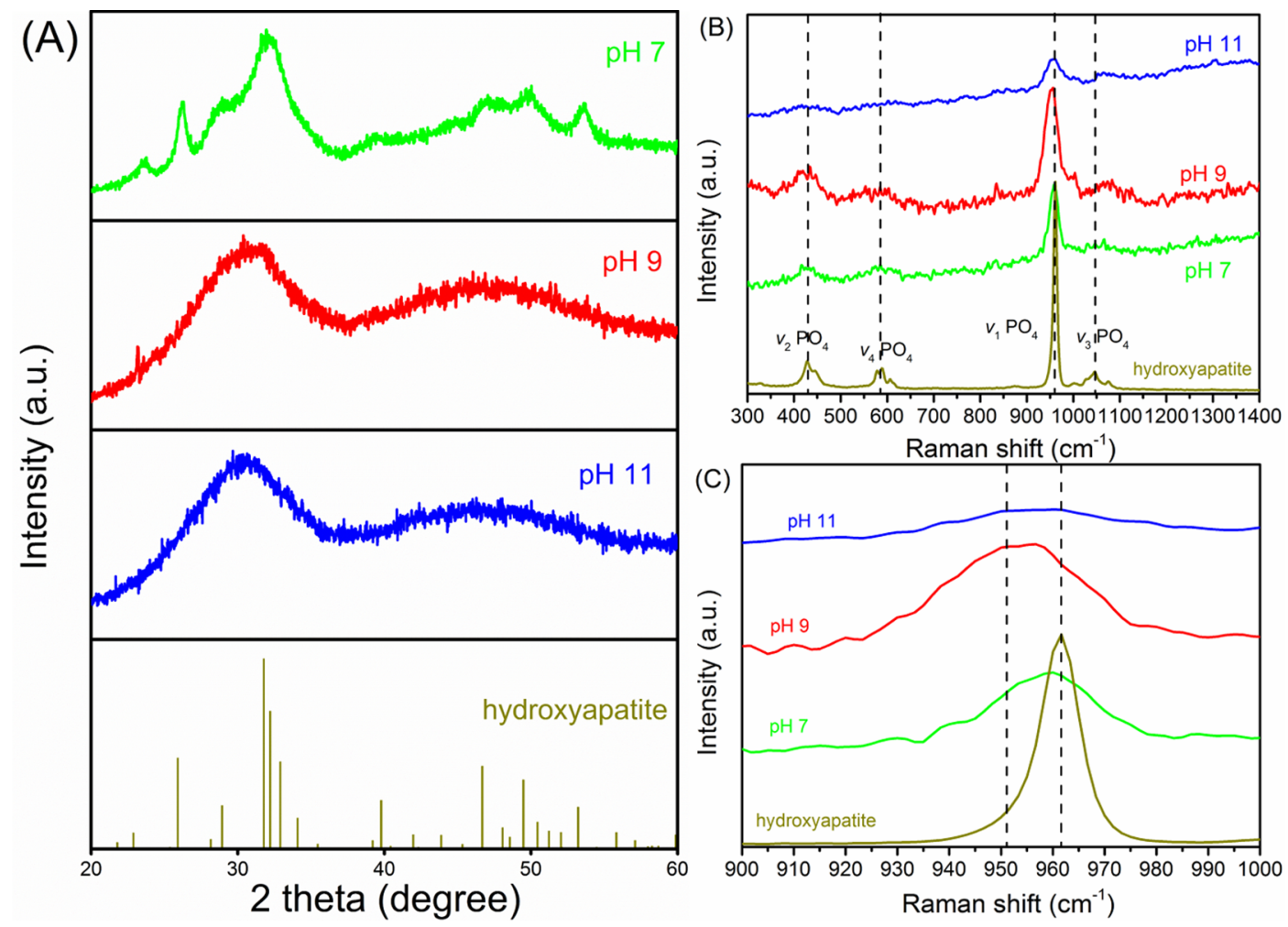

Figure 3. (A) XRD patterns and (B and C) Raman spectra of solids collected at precipitation $\mathrm{pH}$ values of 7, 9, and 11.

at $950 \mathrm{~cm}^{-1} \cdot 34,36,37$ Therefore, the observed frequency change of the $v_{1}\left(\mathrm{PO}_{4}\right)$ mode can serve as an identifier of the crystalline nature of calcium phosphate precipitates collected at low $\mathrm{pH}$ and the amorphous nature of solids collected at high $\mathrm{pH}$ $(\geq 9.0)$. In conclusion, Raman and XRD characterizations confirm the presence of HAP at a low precipitation $\mathrm{pH}(\leq 8.0)$, while at all $\mathrm{pH}$ values, the dominant phase is amorphous calcium phosphate. 


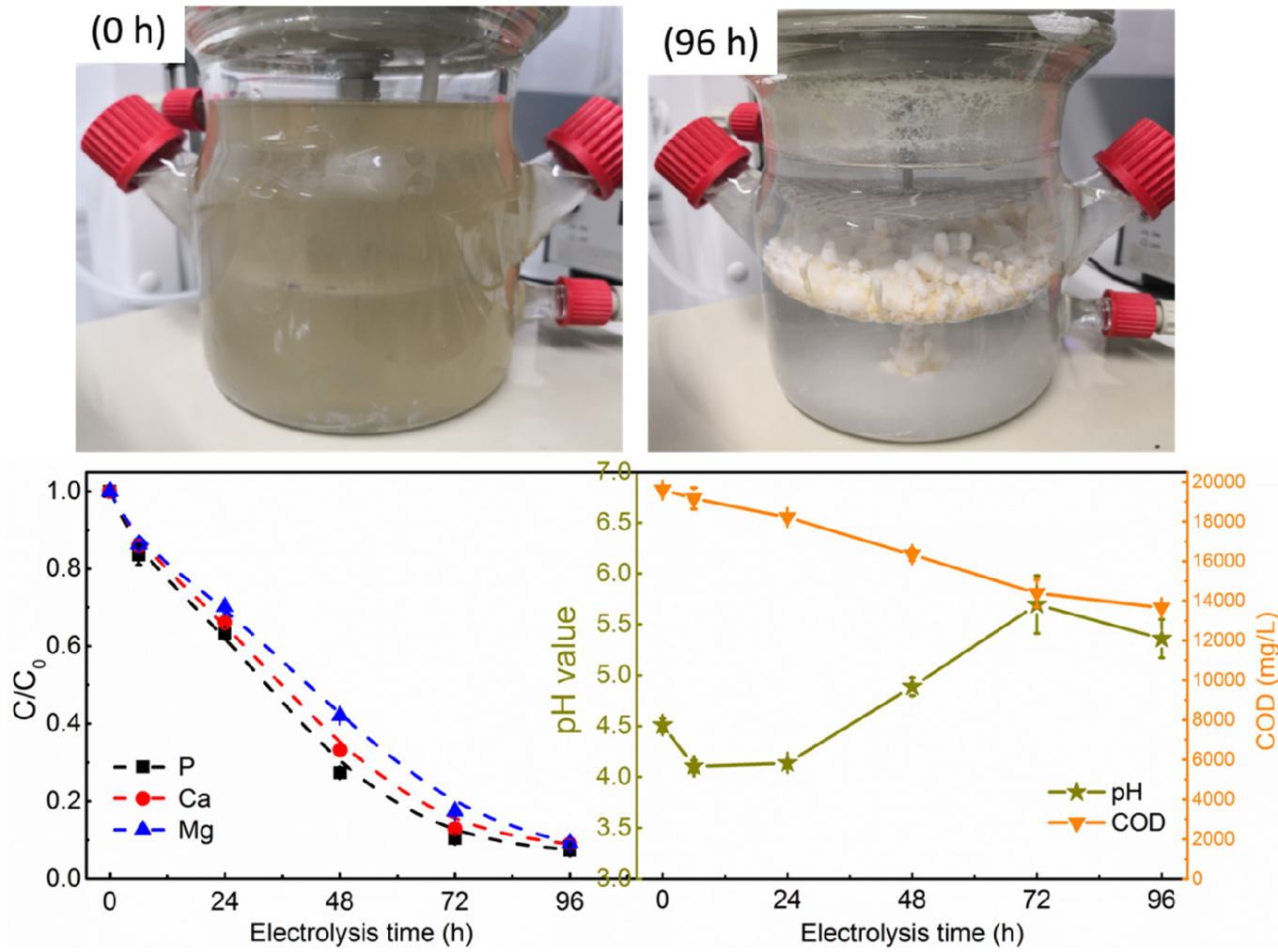

Figure 4. Removal of $\mathrm{P}, \mathrm{Ca}, \mathrm{Mg}$, and $\mathrm{COD}$ and change in wastewater $\mathrm{pH}$ by electrochemical treatment and real images of cheese wastewater before and after electrochemical treatment. Conditions: $200 \mathrm{~mA}$, Pt-Ti mesh anode, Pt-Ti disk cathode, and electrode distance of $3 \mathrm{~cm}$. The cathode is positioned below the anode inside the glass reactor.

3.3. Electrochemical Precipitation. We first demonstrated that electrochemically induced calcium phosphate precipitation in cheese wastewater is possible, although the wastewater has an acidic environment ( $\mathrm{pH} 4.4)$ and contains many organic species. As shown in Figure 4, by electrochemical treatment, cheese wastewater becomes relatively clean and transparent. Moreover, the cathode is covered by deposits. The $\mathrm{P}, \mathrm{Ca}$, and $\mathrm{Mg}$ concentrations decreased gradually over the electrochemical treatment at $200 \mathrm{~mA}$ or $40 \mathrm{~A} / \mathrm{m}^{2}$. The removal efficiencies of all ions were $>90 \%$ after treatment for $96 \mathrm{~h}$. As a result of the removal of ions, we observed precipitates on the cathode and some at the bottom of the electrochemical reactor.

In the electrochemical treatment process, the overall $\mathrm{pH}$ of the wastewater increased from a minimum of 4.5 to a maximum of 5.7, although at the beginning, there is a slight decrease in $\mathrm{pH}$ from 4.5 to 4.1 (Figure 4). On the basis of the thermodynamic calculation, cheese wastewater is already saturated with both HAP and brushite at $\mathrm{pH} \sim 6.0$. Therefore, homogeneous calcium phosphate precipitation might have occurred as the electrochemical treatment proceeded.

While the slight increase in $\mathrm{pH}$ indeed induces homogeneous calcium phosphate precipitation in cheese wastewater, most of the removed calcium and phosphate precipitate on the cathode surface. The solids recovered from the cathode accounted for $92.0 \%$ and $94.2 \%$ of the removed $\mathrm{P}$ and $\mathrm{Ca}$, respectively. For $\mathrm{Mg}$, the rate of recovery from the cathode is as high as $98.4 \%$. This again confirms that the $\mathrm{pH}$ close to the cathode is much higher than the bulk solution's $\mathrm{pH}$. Indeed, Zhang et al. reported an increase in the substrate-solution interface $\mathrm{pH}$ to 7.8 , while the bulk solution $\mathrm{pH}$ is 4.5 at a current density of $30 \mathrm{~A} / \mathrm{m}^{2} .38$ On the basis of the thermodynamic calculation (Figure 1) and the results of chemical precipitation (Figure 2), such an increase in $\mathrm{pH}$ will result in calcium phosphate formation. Therefore, the removal of phosphate is mainly due to its precipitation with calcium ions on the cathode surface, which has a cathodically created local high-pH environment during electrolysis of the cheese water.

Compared to conventional chemical precipitation (see Figure 2), there is an apparent COD removal in the electrochemical process. After treatment for $96 \mathrm{~h}, 29.7 \%$ of COD was removed (Figure 4). The difference between the chemical process and the electrochemical process points out that the main COD removal pathway is probably not the coprecipitation of organics with calcium phosphate. The likely COD removal mechanism in the electrochemical process is the anode-mediated formation of chlorine and associated reactive chlorine species like hypochlorite, which results in the reduction of COD. ${ }^{19,39}$ However, it is worth mentioning that toxic chlorinated organic byproducts may be formed. ${ }^{40}$ After being processed for electrochemical phosphate recovery, the treated cheese wastewater will be diluted $>100$-fold with other industrial wastewaters. It is hypothized that the follow-up biological process will be able to handle the potential present chlorinated byproducts. This hypothesis has to be verified in an additional study.

3.4. Effects of Current. Figure 5 presents the influence of current (density) on electrochemical removal of $\mathrm{P}, \mathrm{Ca}$, and $\mathrm{Mg}$ from cheese wastewater. We can see from Figure 5 that the removal percentage of all ions increased with the increase in current (density) and electrolysis time. Specifically, the system accomplished a maximum $\mathrm{P}$ removal of $34.2 \pm 0.8 \%$ at $50 \mathrm{~mA}$ $\left(10 \mathrm{~A} / \mathrm{m}^{2}\right)$ after treatment for $96 \mathrm{~h}$. This number was 


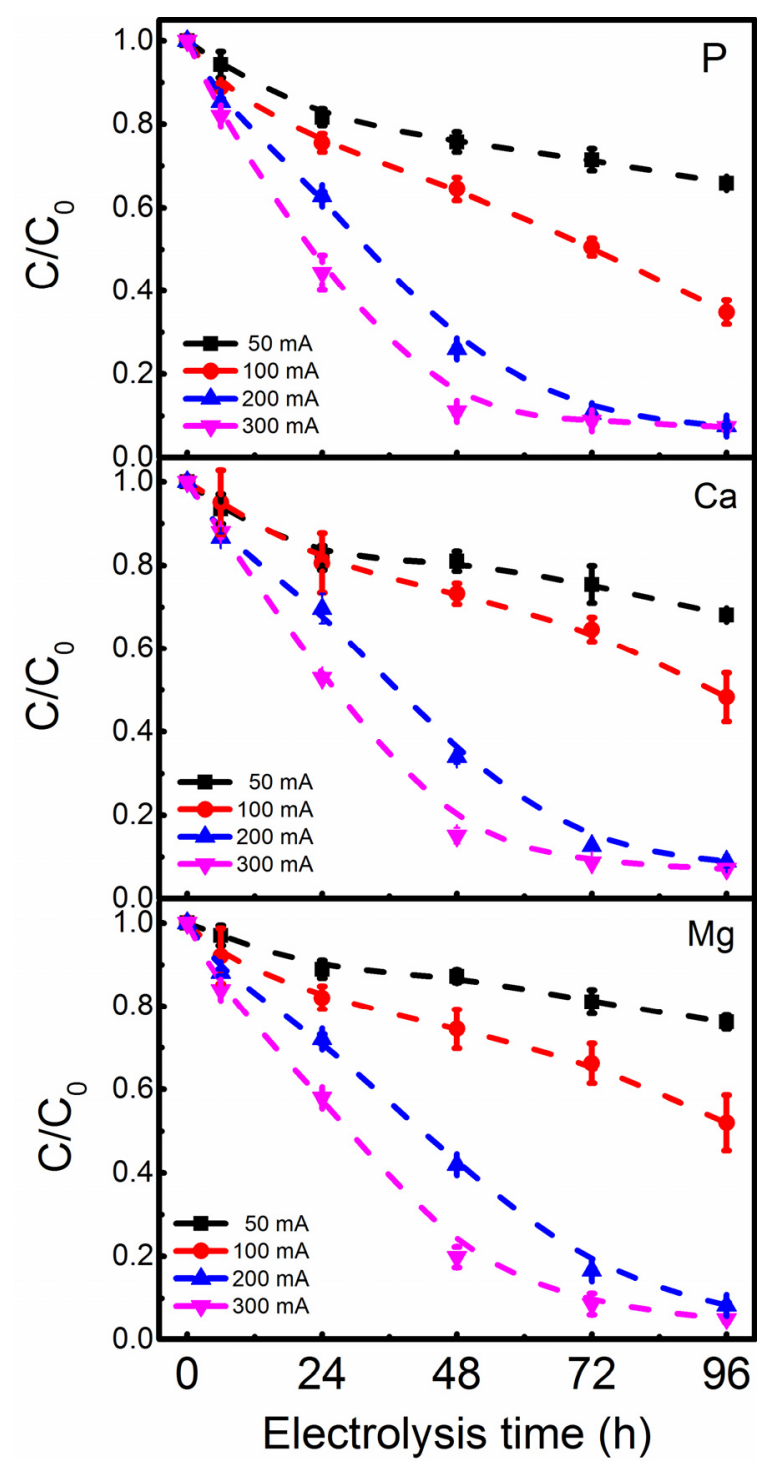

Figure 5. Electrochemical removal of $\mathrm{P}, \mathrm{Ca}$, and $\mathrm{Mg}$ from cheese wastewater as a function of current (density). Conditions: $\mathrm{Pt}-\mathrm{Ti}$ mesh anode, $\mathrm{Pt}-\mathrm{Ti}$ disk cathode, and electrode distance of $3 \mathrm{~cm}$.

increased to $65.2 \pm 2.9 \%$ at $100 \mathrm{~mA}, 92.5 \pm 0.2 \%$ at $200 \mathrm{~mA}$, and $92.7 \pm 0.3 \%$ at $300 \mathrm{~mA}$. The current-dependent removal of $\mathrm{P}$ occurs because the local cathode $\mathrm{pH}$ is regulated by the current, as experimentally verified by Zhang et al. with an in situ $\mathrm{pH}$ microsensor. ${ }^{38}$ Although the final removal efficiency of $\mathrm{P}$ at 200 and $300 \mathrm{~mA}$ is similar, P's removal at $300 \mathrm{~mA}$ is much faster; $88.7 \%$ of $\mathrm{P}$ was removed in $48 \mathrm{~h}$. Therefore, we can decrease the retention time by increasing the current when needed. Nonetheless, the kinetics of electrochemical P removal (heterogeneous) is much lower than that of homogeneous chemical precipitation, which is typically completed in just 0.5 h. The kinetics of the electrochemical approach is limited by the applied current density and the cathode area. While we can increase the removal rate by increasing the current, this will lead to substantial energy consumption. Therefore, it seems the most feasible way to increase the removal rate is by increasing the cathode area. We are working on designing a new type of electrochemical cell that allows us to use tubular stainless steel as the cathode. We hope to improve the low kinetics of the electrochemical approach with this new design.
For $\mathrm{Ca}$, we observed a removal trend similar to that of $\mathrm{P}$ at different currents. This is logical, as the removal of $\mathrm{Ca}$ is directly linked to $\mathrm{P}$ by electrochemically induced calcium phosphate precipitation. The removal of $\mathrm{Mg}$ is also highly dependent on the current. This is explained by the fact that the removal of $\mathrm{Mg}$ is due to the formation and precipitation of $\mathrm{Mg}(\mathrm{OH})_{2}{ }^{13,25}$ The formation of hydroxide ions is regulated by the electric charge passed. This charge is determined by the applied current and electrolysis time. The higher the current density, the higher the local concentration of hydroxide ions. Therefore, the removal rate of $\mathrm{Mg}$ increased with an increase in current density and electrolysis time. The maximum removal of $\mathrm{Mg}$ in our tests was $\sim 95 \%$, which was accomplished in $96 \mathrm{~h}$ at $300 \mathrm{~mA}$.

With regard to Raman characterization, we observed a shift in the $v_{1}\left(\mathrm{PO}_{4}\right)$ stretching (Figure $6 \mathrm{~A}, \mathrm{~B}$ ) similar to that we found in the case of chemical precipitation. At 50 and $100 \mathrm{~mA}$, the frequency of the $v_{1}\left(\mathrm{PO}_{4}\right)$ stretching occurs at $\sim 961 \mathrm{~cm}^{-1}$. However, at $200 \mathrm{~mA}$, it happens at $951 \mathrm{~cm}^{-1}$. Such a shift can be an indicator of the change in crystallinity of calcium phosphate solids. $^{37}$

Consistently, the XRD spectrum of the solids collected under different currents also supports the finding that the degree of crystallinity of calcium phosphate decreased with an increase in current (Figure 6C). This follows the findings for chemical precipitation, in which a higher precipitation $\mathrm{pH}$ results in more ACP formation. The current regulates the production of hydroxide ions at the cathode. The higher the current, the larger the amount of hydroxide ions produced. However, it is worth mentioning that a conventionally high current density or a high $\mathrm{pH}$ is believed to promote the formation of crystalline species. The inverse effects we observed are probably connected to the cheese wastewater's unique characteristics compared to synthetic solutions and other low-strength waste streams (i.e., domestic sewage). According to Figure 5, the removal of $\mathrm{Mg}$ strongly depends on the applied current. Ferguson and McCarty reported that the coprecipitation of $\mathrm{Mg}$ with calcium phosphate severely inhibits the transfer of ACP to HAP because $\mathrm{Mg}^{2+}$ competes with chemically similar but larger $\mathrm{Ca}^{2+}$ for structural sites. ${ }^{41}$ The significant removal of $\mathrm{Mg}(>90 \%)$ at 200 and $300 \mathrm{~mA}$ may affect ACP's evolution to crystalline calcium phosphate. However, the removal rate of $\mathrm{Mg}$ is below $50 \%$ at 50 and $100 \mathrm{~mA}$, allowing the partial formation of crystalline species. As a result, we observed a decrease in crystallinity with an increase in current.

We also noticed an intense bond near $1076 \mathrm{~cm}^{-1}$ in the Raman spectra (Figure 6B). This bond is probably linked to the symmetric $\nu_{1}\left(\mathrm{CO}_{3}\right)$ stretching mode of the carbonate molecule. ${ }^{36}$ However, such $\nu_{1}\left(\mathrm{CO}_{3}\right)$ carbonate bond stretching was not found in chemical precipitation (Figure 3C). The observed new stretching bond suggests that there might be calcium carbonate coprecipitation in the electrochemical system. The involvement of carbonate may come from $\mathrm{CO}_{2}$, which is produced from the mineralization of organic compounds in cheese wastewater by electrochemical treatment (direct anode oxidation or hypochlorite oxidation ${ }^{28}$ ). We can see from Figure $6 \mathrm{~B}$ that the relative intensity of $\nu_{1}\left(\mathrm{CO}_{3}\right)$ to $\nu_{1}\left(\mathrm{PO}_{4}\right)$ stretching increased with an increase in current, which indicates the increased level of formation of $\mathrm{CaCO}_{3}$ with an increase in current. This is the same as the removal of COD as a function of current. The current determines the degree of COD conversion, so as the formation of $\mathrm{CO}_{2}$, which 

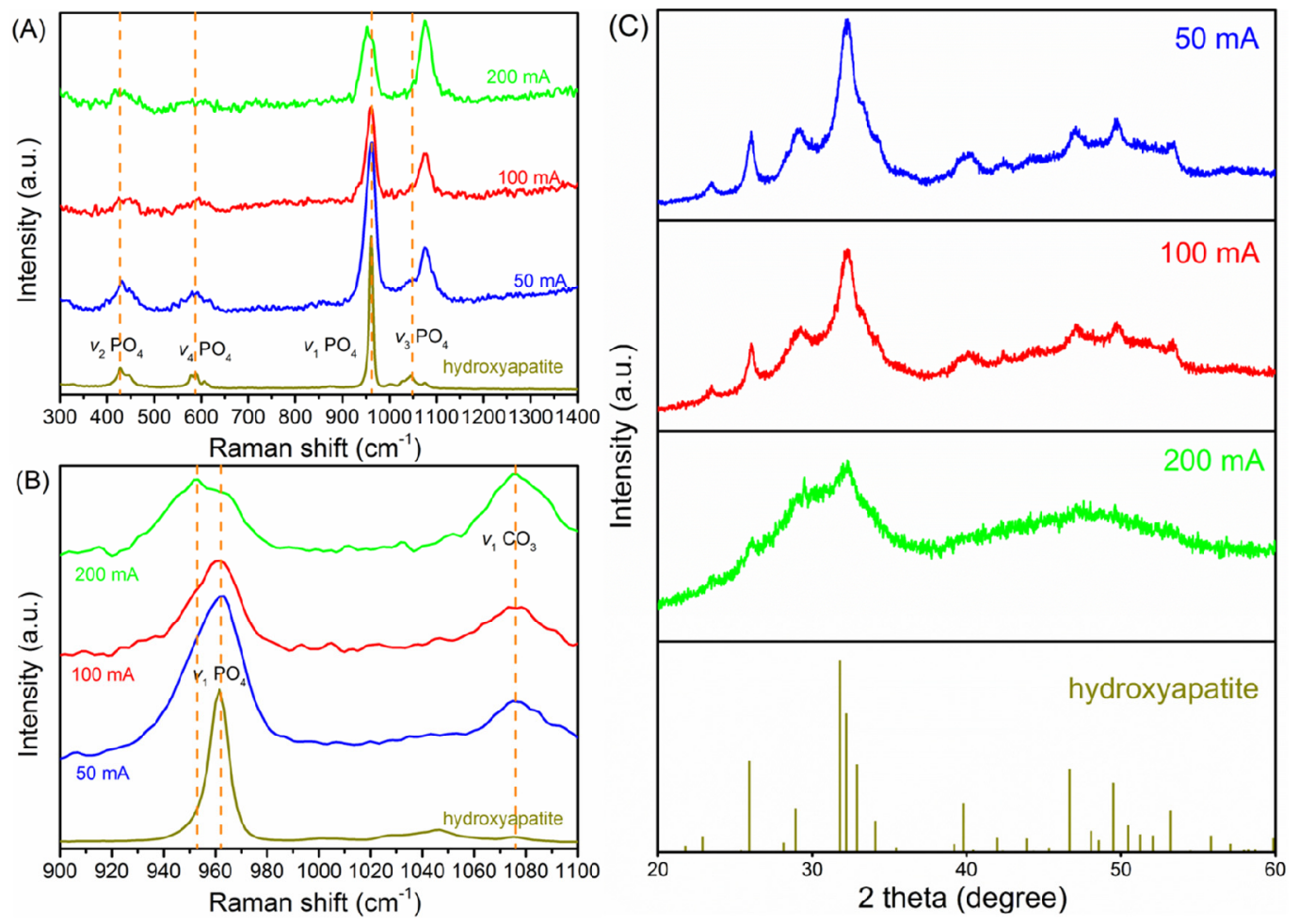

Figure 6. (A and B) Raman spectra and (C) XRD patterns of electrochemically precipitated solids collected at $50 \mathrm{~mA}\left(10 \mathrm{~A} / \mathrm{m}^{2}\right), 100 \mathrm{~mA}(20 \mathrm{~A} /$ $\left.\mathrm{m}^{2}\right)$, and $200 \mathrm{~mA}\left(40 \mathrm{~A} / \mathrm{m}^{2}\right)$.

subsequently interacts with the electrochemically produced hydroxide ions at the cathode, being converted to $\mathrm{HCO}_{3}{ }^{-}$and $\mathrm{CO}_{3}{ }^{2-}$, and then reacts with calcium ions, forming $\mathrm{CaCO}_{3}$.

The involvement of carbonate precipitation was also evidenced by the $\mathrm{Ca} / \mathrm{P}$ removal molar ratio. In the case of chemical precipitation, regardless of the precipitation $\mathrm{pH}$, the removed $\mathrm{Ca} / \mathrm{P}$ atomic ratio is $1.45 \pm 0.04$, below the theoretical highest $\mathrm{Ca} / \mathrm{P}$ atomic ratio (1.67 for $\mathrm{HAP}$ ). However, in the electrochemical system, the removed $\mathrm{Ca} / \mathrm{P}$ molar ratio is $1.99 \pm 0.15$. This is probably due to the formation and precipitation of $\mathrm{CaCO}_{3}$ that removes extra $\mathrm{Ca}$ and thus results in a higher $\mathrm{Ca} / \mathrm{P}$ removal ratio. On the basis of Raman characterization and the associated $\mathrm{Ca} / \mathrm{P}$ ratios, we firmly assume the formation of $\mathrm{CaCO}_{3}$ in electrochemical treatment of cheese wastewater, in addition to calcium phosphate. Nonetheless, the solids recovered in cheese wastewater are still dominated by calcium phosphate rather than $\mathrm{CaCO}_{3}$ that we have seen in the electrochemical treatment of domestic sewage. ${ }^{27}$

3.5. Energy Consumption. While a higher current density and a longer treatment time will undoubtedly result in a higher removal efficiency, the associated energy consumption is also increased. To determine the best conditions for the energyefficient removal of $\mathrm{P}$, we plotted the amount of removed $\mathrm{P}$ as a function of energy consumption (Figure 7) by multiplying the applied current, the recorded cell voltage, and electrolysis time. Because of the very high conductivity $(\sim 200 \mathrm{mS} / \mathrm{cm})$ of cheese wastewater, the increase in the current did not affect the cell voltage that much. The cell voltages were $2.81,2.93,3.05$, and $3.12 \mathrm{~V}$ at 50,100, 200, and $300 \mathrm{~mA}$, respectively (Table S1).

Figure 7 shows that this system is more energy-efficient when operated at a higher current. For example, when the energy consumption is around $20 \mathrm{~W} \mathrm{~h}, 436 \pm 36 \mathrm{mg}$ of $\mathrm{P}$ is

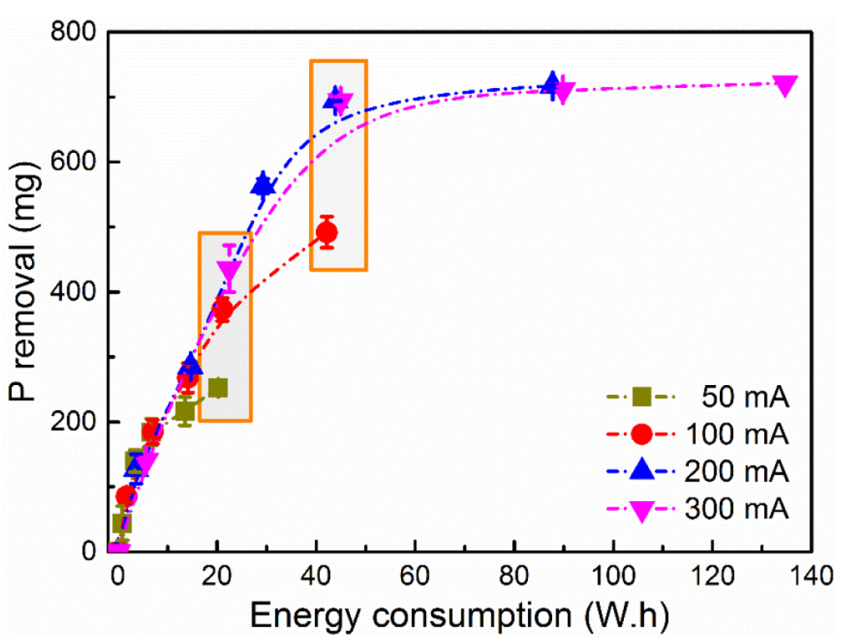

Figure 7. Absolute removal of $\mathrm{P}$ as a function of current and electrolysis time. The energy consumption is calculated by multiplying the recorded cell voltage, applied current, and electrolysis time.

removed at $300 \mathrm{~mA}$, whereas this value is $253 \pm 7 \mathrm{mg}$ at 50 $\mathrm{mA}$ and $373 \pm 18 \mathrm{mg}$ at $100 \mathrm{~mA}$. Considering the removal efficiency, energy consumption, and kinetics, the best working condition seems to be $300 \mathrm{~mA}$. In such a situation, a satisfying removal efficiency $(88.9 \%)$ was achieved in a durable retention time $(48 \mathrm{~h})$ at a reasonable energy consumption $(44.9 \mathrm{~W} \mathrm{~h})$. Given this process will be applied as a pretreatment step, the remaining $11.1 \% \mathrm{P}$ in cheese wastewater can be mixed with other industrial wastewater and used as nutrients to support the growth of bacteria in the biological process. The normalized specific energy consumption for the recovery of $\mathrm{P}$ from cheese wastewater is $64.7 \mathrm{kWh} / \mathrm{kg}$ of $\mathrm{P}$ or 5.8 euros $/ \mathrm{kg}$ of $\mathrm{P}$ assuming the price of electricity is 0.09 euro/kWh. While 
this electricity consumption cannot be fully justified by the recovered phosphate $(1-2$ euros $/ \mathrm{kg}$ of $\mathrm{P})$, the added value of electrochemical treatment (i.e., reduced COD and disinfection), which is not addressed in this study, may justify the adoption of the electrochemical approach. In addition, if we consider the potential increase in the price of $\mathrm{P}$ fertilizer, as a result of the decrease in the quality and quantity of phosphate rock reserves, electrochemical recovery of phosphate from cheese wastewater as a pretreatment step added to an industrial wastewater treatment plant could hold promise.

With regard to the electricity consumption and chemical cost, the values of the electrochemical approach (5.7-7.7 euros $/ \mathrm{kg}$ of $\mathrm{P}$ ) are already higher than those of the traditional chemical precipitation approach (1.34-1.80 euros $/ \mathrm{kg}$ of $\mathrm{P}$ ) even if we only consider the electricity consumption and chemical dosing for electrochemical and chemical methods, respectively (Tables S1 and S2). Moreover, although it is too early to calculate the CAPEX at proof of the feasibility stage, the CAPEX of the electrochemical approach is likely much higher than that of chemical precipitation. Therefore, we need to improve the cell configuration to maximize phosphate removal while minimizing investment costs and energy consumption. It was previously demonstrated that the in situ production of acid and base with a bipolar membrane electrolysis cell is $40 \%$ cheaper than purchasing commercial chemicals. $^{42}$ On top of CAPEX and OPEX, we should also consider the unique advantages of the electrochemical approach, i.e., no requirement of adjustment of $\mathrm{pH}$ or dosing chemicals, producing recyclable solids instead of chemical sludge. Collectively, the electrochemical method has several advantages over chemical precipitation and could be a solution for some waste streams, i.e., cheese wastewater.

3.6. Can the Recovered Solids Work as Fertilizer? Table 2 presents the main element composition of the recovered solids in both electrochemical and chemical precipitation. Overall, there is no significant difference with regard to $\mathrm{P}$ contents between chemical and electrochemical precipitation. In electrochemical systems, the $\mathrm{P}$ content of recovered solids was between $9.4 \%$ and $13.4 \%$ and decreased with current (density). In chemical precipitation, the $\mathrm{P}$ content decreased from $12.3 \%$ at $\mathrm{pH} 7.0$ to $11.0 \%$ at $\mathrm{pH} 11.0$.

Remarkably, although the amount of $\mathrm{P}$ in the recovered solids decreased with precipitation $\mathrm{pH}$ or the applied current, the $\mathrm{P}$ content is still higher than that of the incinerated sludge ash in Germany $(9 \%)^{43}$ and comparable to that of the highgrade phosphate rock $(13 \%){ }^{44}$ It is worth mentioning that our solids were dried at room temperature $\left(23 \pm 1{ }^{\circ} \mathrm{C}\right)$. The solids lost approximately $10 \%$ of their weight when dried at $105^{\circ} \mathrm{C}$ in the oven. When this is taken into account, our solids have a $\mathrm{P}$ content of $\leq 14.9 \%$ and comply with the requirement of the fertilizer industry $(>11 \%){ }^{45}$ This $\mathrm{P}$ content is already close to the $\mathrm{P}$ content of calcium phosphate granules recovered from black water in a UASB reactor after the removal of $29 \%$ organic components by incineration. ${ }^{46}$ The $\mathrm{P}$ content of our recovered solids will be even higher if incineration is applied. However, in light of the satisfied $\mathrm{P}$ contents, the energy-intensive incineration process is not required.

The heavy metals in the recovered solids are negligible. The solids recovered under $50 \mathrm{~mA}$ contain the largest amount of heavy metals but still at a level lower than regulation limits. ${ }^{47}$ The heavy metals present at most were iron ( $\mathrm{Fe}, 1188 \pm 173$ $\mathrm{mg} / \mathrm{kg}$ of dried solids), followed by aluminum (Al, $321 \pm 90$ $\mathrm{mg} / \mathrm{kg}$ ) and zinc (Zn, $256 \pm 19 \mathrm{mg} / \mathrm{kg})$. The dried solids also

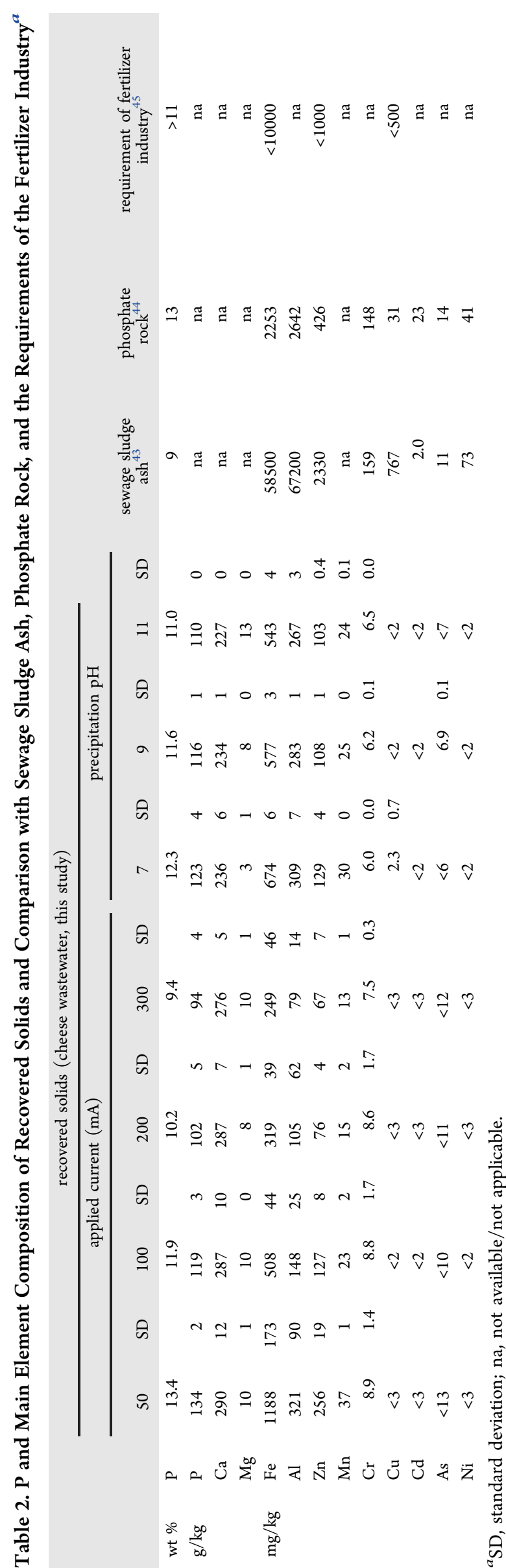


have a tiny amount of manganese $(\mathrm{Mn}, 37 \pm 1 \mathrm{mg} / \mathrm{kg})$ and chromium $(\mathrm{Cr}, 9 \pm 1 \mathrm{mg} / \mathrm{kg})$. Toxic metals $\mathrm{Cd}$ and As, which are often found in phosphate rock at high levels, were not detected (normalized detection limit in our case: As, $10 \mathrm{mg} /$ $\mathrm{kg}$; Cd, $2 \mathrm{mg} / \mathrm{kg}$ ). Similarly, Fe, Al, Zn, Mn, and $\mathrm{Cr}$ were also detected in the case of chemical precipitation, but all at very low levels. The total amount of heavy metals present in the solids from chemical precipitation is $<1.5 \mathrm{~g} / \mathrm{kg}$.

The significantly low level of contamination of heavy metals originates from the "clean" nature of the wastewater. The wastewater is generated from the cheese production process and was not polluted by human waste or industrial waste, which otherwise would bring heavy metals into these solids. This also reminds us of the importance of directly recovering phosphorus from cheese wastewater before it is mixed with human or industrial waste.

The bioavailability test reveals the high availability of $\mathrm{P}$ in the recovered solids from both chemical and electrochemical precipitation processes (Table S3). In distilled water, the release of $\mathrm{P}$ is $<0.3 \%$. However, $>80 \%$ of total $\mathrm{P}$ was released after exposure for $0.5 \mathrm{~h}$ to $2 \%$ citric acid solutions. This value is slightly lower than commercial ACP (95.3\%) but much higher than the P released from commercial HAP (44.5\%) and is also higher than the $\mathrm{P}$ bioavailability of solids recovered from black water by UASB reactors $(35 \%)^{46}$ or the P availability of many other products recovered from waste streams $(37.1-67.9 \%){ }^{48}$ Therefore, the recovered solids can be recycled as a safe raw material for producing $\mathrm{P}$ fertilizer without incineration or applied directly as $\mathrm{P}$ fertilizer.

\section{CONCLUSION}

Cheese wastewater is a promising source for phosphorus recovery. Although it has an acidic matrix and a high level of organics, we demonstrated that through a simple electrochemical treatment, we could recover phosphate from cheese wastewater in the form of recyclable calcium phosphate without dosing external chemicals. This is of particular interest in on-site treatment, where a modular electrochemical system can be introduced. Consequently, the transport and storage of corrosive acidic or alkaline chemicals are not required. The recovered calcium phosphate solids contain a high level of $\mathrm{P}$ of $\leq 13 \%$, which is higher than the fertilizer industry's requirement. Because of the acidic $\mathrm{pH}$, the products recovered from cheese wastewater have a low percentage of $\mathrm{CaCO}_{3}$.

Moreover, because of the "clean" nature of cheese wastewater, the products have a low risk of heavy metal contamination. Therefore, it complies with almost all regulation limits regarding the recycling of solids as raw material for producing phosphorus fertilizer or other valueadded phosphorus products (i.e., flame retardants). It could even be used as a natural phosphorus fertilizer. On top of phosphorus recovery, the electrochemical treatment has some other benefits, such as removing color, turbidity, and COD to a certain extent, and even the disinfection of cheese wastewater, as reported elsewhere. Collectively, our study suggests the electrochemical approach can be a good pretreatment strategy for treating high-strength waste streams, i.e., cheese wastewater, providing the energy consumption and cell design can be optimized in the future study.

\section{ASSOCIATED CONTENT}

\section{Supporting Information}

The Supporting Information is available free of charge at https://pubs.acs.org/doi/10.1021/acsestwater.0c00263.

Change in total and soluble COD in cheese wastewater as a function of precipitation $\mathrm{pH}$ (Figure S1), change in soluble and total $\mathrm{P}$ concentration in cheese wastewater by chemical precipitation after settling for $0.5 \mathrm{~h}$ (Figure S2), energy consumption in electrochemical recovery of $\mathrm{P}$ from cheese wastewater at different currents (Table S1), cost of chemical precipitation via $\mathrm{NaOH}$ dosing at different precipitation $\mathrm{pH}$ values (Table S2), and solubility of recovered solids in water and a $2 \%$ citric acid solution and its comparison with commercial hydroxyapatite (HAP) and amorphous calcium phosphate (ACP) (Table S3) (PDF)

\section{AUTHOR INFORMATION}

\section{Corresponding Authors}

Yang Lei - Wetsus, Centre of Excellence for Sustainable Water Technology, 8900CC Leeuwarden, The Netherlands; Department of Environmental Technology, Wageningen University and Research, 6700AA Wageningen, The Netherlands; School of Environmental Science and Engineering, Southern University of Science and Technology (SUSTech), Shenzhen 518055, China; 이이.org/00000003-0709-4743; Email: leiyangsustech@126.com

Renata D. van der Weijden - Wetsus, Centre of Excellence for Sustainable Water Technology, 8900CC Leeuwarden, The Netherlands; Department of Environmental Technology, Wageningen University and Research, 6700AA Wageningen, The Netherlands; Email: renata.vanderweijden@wur.nl

\section{Authors}

Zhengshuo Zhan - Wetsus, Centre of Excellence for Sustainable Water Technology, 8900CC Leeuwarden, The Netherlands; Department of Environmental Technology, Wageningen University and Research, 6700AA Wageningen, The Netherlands

Michel Saakes - Wetsus, Centre of Excellence for Sustainable Water Technology, 8900CC Leeuwarden, The Netherlands

Cees J. N. Buisman - Wetsus, Centre of Excellence for Sustainable Water Technology, 8900CC Leeuwarden, The Netherlands; Department of Environmental Technology, Wageningen University and Research, 6700AA Wageningen, The Netherlands

Complete contact information is available at:

https://pubs.acs.org/10.1021/acsestwater.0c00263

\section{Notes}

The authors declare no competing financial interest.

\section{ACKNOWLEDGMENTS}

This work was performed in the cooperation framework of Wetsus, European Centre of Excellence for Sustainable Water Technology (www.wetsus.eu). Wetsus is co-funded by the Dutch Ministry of Economic Affairs and the Ministry of Infrastructure and Environment, the European Union Regional Development Fund, the Province of Fryslân, and the Northern Netherlands Provinces. This research has received funding from NWO (The Dutch Research Council) under NWO Take-off Grant Agreement 18283. The authors are grateful to 
the participants of the research theme "Resource Recovery" for fruitful discussions and financial support.

\section{REFERENCES}

(1) Kolev Slavov, A. Dairy Wastewaters: General characteristics and treatment possibilities of dairy wastewater-A review. Food Technol. Biotechnol. 2017, 55 (1), 14-28.

(2) IndexMundi Dairy, Cheese Production by Country in 1000 MT. https://www.indexmundi.com/agriculture/?commodity= cheese\&graph $=$ production (last accessed 2021-01-25).

(3) Danalewich, J.; Papagiannis, T. G.; Belyea, R. L.; Tumbleson, M. E.; Raskin, L. Characterization of dairy waste streams, current treatment practices, and potential for biological nutrient removal. Water Res. 1998, 32 (12), 3555-3568.

(4) Carvalho, F.; Prazeres, A. R.; Rivas, J. Cheese whey wastewater: characterization and treatment. Sci. Total Environ. 2013, 445, 385396.

(5) Ahmad, T.; Aadil, R. M.; Ahmed, H.; Rahman, U. u.; Soares, B. C. V.; Souza, S. L. Q.; Pimentel, T. C.; Scudino, H.; Guimarães, J. T.; Esmerino, E. A.; Freitas, M. Q.; Almada, R. B.; Vendramel, S. M. R.; Silva, M. C.; Cruz, A. G. Treatment and utilization of dairy industrial waste: A review. Trends Food Sci. Technol. 2019, 88, 361-372.

(6) Charalambous, P.; Shin, J.; Shin, S. G.; Vyrides, I. Anaerobic digestion of industrial dairy wastewater and cheese whey: Performance of internal circulation bioreactor and laboratory batch test at $\mathrm{pH}$ 5-6. Renewable Energy 2020, 147, 1-10.

(7) Yonar, T.; Sivrioğlu, Ö.; Özengin, N. Physico-Chemical Treatment of Dairy Industry Wastewaters: A Review. In Technological Approaches for Novel Applications in Dairy Processing; Koca, N., Ed.; IntechOpen, 2018.

(8) Prazeres, A. R.; Rivas, J.; Almeida, M. A.; Patanita, M.; Dôres, J.; Carvalho, F. Agricultural reuse of cheese whey wastewater treated by $\mathrm{NaOH}$ precipitation for tomato production under several saline conditions and sludge management. Agricultural Water Management 2016, 167, 62-74.

(9) Prazeres, A. R.; Luz, S.; Fernandes, F.; Jerónimo, E. Cheese wastewater treatment by acid and basic precipitation: Application of $\mathrm{H}_{2} \mathrm{SO}_{4}, \mathrm{HNO}_{3}, \mathrm{HCl}, \mathrm{Ca}(\mathrm{OH})_{2}$ and $\mathrm{NaOH}$. J. Environ. Chem. Eng. 2020, 8 (2), 103556.

(10) Prazeres, A. R.; Fernandes, F.; Luz, S.; Jerónimo, E. Simple processes for contamination removal in cheesemaking wastewater: $\mathrm{CaCO}_{3}, \mathrm{Mg}(\mathrm{OH})_{2}, \mathrm{FeSO}_{4}$ and $\mathrm{FeCl}_{3}$. J. Environ. Chem. Eng. 2020, 8 (4), 104034.

(11) Guerreiro, R. C. S.; Jeronimo, E.; Luz, S.; Pinheiro, H. M.; Prazeres, A. R. Cheese manufacturing wastewater treatment by combined physicochemical processes for reuse and fertilizer production. J. Environ. Manage. 2020, 264, 110470.

(12) Lei, Y.; Song, B.; van der Weijden, R. D.; Saakes, M.; Buisman, C. J. Electrochemical induced calcium phosphate precipitation: Importance of local pH. Environ. Sci. Technol. 2017, 51 (19), 11156-11164.

(13) Lei, Y.; Remmers, J.; van der Weijden, R. D.; Saakes, M.; Buisman, C. J. Is there a precipitation sequence in municipal wastewater induced by electrolysis? Environ. Sci. Technol. 2018, 52 (15), 8399-8407.

(14) Perera, M. K.; Englehardt, J. D.; Cohn, J. L.; Dauer, E. A.; Shukla, D. Electrohydromodulation for Phosphate Recovery from Wastewater. Sep. Purif. Technol. 2020, 247, 116909.

(15) Hug, A.; Udert, K. M. Struvite precipitation from urine with electrochemical magnesium dosage. Water Res. 2013, 47 (1), 289299.

(16) Tezcan Un, U.; Kandemir, A.; Erginel, N.; Ocal, S. E. Continuous electrocoagulation of cheese whey wastewater: an application of response surface methodology. J. Environ. Manage. 2014, 146, 245-250.

(17) Benazzi, T. L.; Di Luccio, M.; Dallago, R. M.; Steffens, J.; Mores, R.; Do Nascimento, M. S.; Krebs, J.; Ceni, G. Continuous flow electrocoagulation in the treatment of wastewater from dairy industries. Water Sci. Technol. 2016, 73 (6), 1418-1425.
(18) Markou, V.; Kontogianni, M.-C.; Frontistis, Z.; Tekerlekopoulou, A. G.; Katsaounis, A.; Vayenas, D. Electrochemical treatment of biologically pre-treated dairy wastewater using dimensionally stable anodes. J. Environ. Manage. 2017, 202, 217-224.

(19) Tirado, L.; Gökkuş, Ö.; Brillas, E.; Sirés, I. Treatment of cheese whey wastewater by combined electrochemical processes. J. Appl. Electrochem. 2018, 48 (12), 1307-1319.

(20) Bruguera-Casamada, C.; Araujo, R. M.; Brillas, E.; Sirés, I. Advantages of electro-Fenton over electrocoagulation for disinfection of dairy wastewater. Chem. Eng. J. 2019, 376, 119975.

(21) Udert, K. M. Phosphorus as a resource. Phosphorus: Polluter and Resource 2018, 57, 57.

(22) Cordell, D.; Drangert, J.-O.; White, S. The story of phosphorus: Global food security and food for thought. Global Environmental Change 2009, 19 (2), 292-305.

(23) Mayer, B. K.; Baker, L. A.; Boyer, T. H.; Drechsel, P.; Gifford, M.; Hanjra, M. A.; Parameswaran, P.; Stoltzfus, J.; Westerhoff, P.; Rittmann, B. E. Total value of phosphorus recovery. Environ. Sci. Technol. 2016, 50 (13), 6606-6620.

(24) Lei, Y. Electrochemical phosphorus removal and recovery. $\mathrm{Ph} . \mathrm{D}$. Thesis, Wageningen University, Wageningen, The Netherlands, 2019.

(25) Lei, Y.; Hidayat, I.; van der Weijden, R. D.; Saakes, M.; Buisman, C. J. Fate of calcium, magnesium and inorganic carbon in electrochemical phosphorus recovery from domestic wastewater. Chem. Eng. J. 2019, 362, 453-459.

(26) van der Houwen, J. A.; Valsami-Jones, E. The application of calcium phosphate precipitation chemistry to phosphorus recovery: the influence of organic ligands. Environ. Technol. 2001, 22 (11), 1325-35.

(27) Lei, Y.; Remmers, J. C.; Saakes, M.; van der Weijden, R. D.; Buisman, C. J. N. Influence of cell configuration and long-term operation on electrochemical phosphorus recovery from domestic wastewater. ACS Sustainable Chem. Eng. 2019, 7 (7), 7362-7368.

(28) Lei, Y.; Saakes, M.; van der Weijden, R. D.; Buisman, C. J. Electrochemically mediated calcium phosphate precipitation from phosphonates: Implications on phosphorus recovery from nonorthophosphate. Water Res. 2020, 169, 115206.

(29) Lei, Y.; Song, B.; van der Weijden, R. D.; Saakes, M.; Buisman, C. J. Interaction of calcium, phosphorus and natural organic matter in electrochemical recovery of phosphate. Water Res. 2018, 142, 10-17.

(30) Verband Deutscher Landwirtschaftlicher Untersuchungs und Forschungsanstalten (VDLUFA). Düengemitteluntersuchung - Phosphat (Citronensäurelöslichen) Methoden Buch II. 1995.

(31) Puigdomènech, I. Chemical equilibrium software Hydra and Medusa; Inorganic Chemistry Department, Technology Institute: Stockholm, 2001 (https://www.kth.se/che/medusa/downloads-1. 386254).

(32) Song, Y.; Hahn, H. H.; Hoffmann, E. Effects of solution conditions on the precipitation of phosphate for recovery: A thermodynamic evaluation. Chemosphere 2002, 48 (10), 1029-1034.

(33) Cao, X.; Harris, W. Carbonate and magnesium interactive effect on calcium phosphate precipitation. Environ. Sci. Technol. 2008, 42 (2), 436-442.

(34) Arifin, M.; Swedlund, P. J.; Hemar, Y.; McKinnon, I. R. Calcium phosphates in $\mathrm{Ca}^{2+}$-fortified milk: phase identification and quantification by Raman spectroscopy. J. Agric. Food Chem. 2014, 62 (50), 12223-12228

(35) Hermassi, M.; Valderrama, C.; Dosta, J.; Cortina, J. L.; Batis, N. $\mathrm{H}$. Evaluation of hydroxyapatite crystallization in a batch reactor for the valorization of alkaline phosphate concentrates from wastewater treatment plants using calcium chloride. Chem. Eng. J. 2015, 267, $142-152$.

(36) Ensikat, H.-J.; Geisler, T.; Weigend, M. A first report of hydroxylated apatite as structural biomineral in Loasaceae-plants' teeth against herbivores. Sci. Rep. 2016, 6, 26073.

(37) Stammeier, J. A.; Purgstaller, B.; Hippler, D.; Mavromatis, V.; Dietzel, M. In-situ Raman spectroscopy of amorphous calcium 
phosphate to crystalline hydroxyapatite transformation. MethodsX 2018, 5, 1241-1250.

(38) Zhang, J.; Lin, C.; Feng, Z.; Tian, Z. Mechanistic studies of electrodeposition for bioceramic coatings of calcium phosphates by an in situ pH-microsensor technique. J. Electroanal. Chem. 1998, 452 (2), 235-240.

(39) Markou, V.; Kontogianni, M. C.; Frontistis, Z.; Tekerlekopoulou, A. G.; Katsaounis, A.; Vayenas, D. Electrochemical treatment of biologically pre-treated dairy wastewater using dimensionally stable anodes. J. Environ. Manage. 2017, 202 (Part 1), 217224.

(40) Zöllig, H.; Remmele, A.; Fritzsche, C.; Morgenroth, E.; Udert, K. M. Formation of chlorination byproducts and their emission pathways in chlorine mediated electro-oxidation of urine on active and nonactive type anodes. Environ. Sci. Technol. 2015, 49 (18), 11062-11069.

(41) Ferguson, J. F.; McCarty, P. L. Effects of carbonate and magnesium on calcium phosphate precipitation. Environ. Sci. Technol. 1971, 5 (6), 534-540.

(42) Davis, J. R.; Chen, Y.; Baygents, J. C.; Farrell, J. Production of acids and bases for ion exchange regeneration from dilute salt solutions using bipolar membrane electrodialysis. ACS Sustainable Chem. Eng. 2015, 3 (9), 2337-2342.

(43) Herzel, H.; Kruger, O.; Hermann, L.; Adam, C. Sewage sludge ash-A promising secondary phosphorus source for fertilizer production. Sci. Total Environ. 2016, 542 (Part B), 1136-1143.

(44) Kratz, S.; Schick, J.; Schnug, E. Trace elements in rock phosphates and $\mathrm{P}$ containing mineral and organo-mineral fertilizers sold in Germany. Sci. Total Environ. 2016, 542 (Part B), 1013-1019.

(45) Schipper, W. J.; Klapwijk, A.; Potjer, B.; Rulkens, W. H.; Temmink, B. G.; Kiestra, F. D.; Lijmbach, A. C. Phosphate recycling in the phosphorus industry. Environ. Technol. 2001, 22 (11), 13371345.

(46) Cunha, J. R.; Schott, C.; van der Weijden, R. D.; Leal, L. H.; Zeeman, G.; Buisman, C. Calcium phosphate granules recovered from black water treatment: A sustainable substitute for mined phosphorus in soil fertilization. Resources, Conservation and Recycling 2020, 158, 104791.

(47) Ehlert, P.; Posthuma, L.; Römkens, P.; Rietra, R.; Wintersen, A.; Van Wijnen, H.; van Dijk, T.; van Schöll, L.; Groenenberg, J. Appraising fertilisers: origins of current regulations and standards for contaminants in fertilisers: background of quality standards in the Netherlands, Denmark, Germany, United Kingdom and Flanders; Wettelijke Onderzoekstaken Natuur \& Milieu, 2013.

(48) Wollmann, I.; Gauro, A.; Müller, T.; Möller, K. Phosphorus bioavailability of sewage sludge-based recycled fertilizers. J. Plant Nutr. Soil Sci. 2018, 181 (2), 158-166. 